\title{
Northward expanding resident species benefit from warming winters through increased foraging rates and predator vigilance
}

\author{
Veli-Matti Pakanen $^{1}\left[\right.$ D Eveliina Ahonen ${ }^{1} \cdot$ Esa Hohtola $^{1} \cdot$ Seppo Rytkönen $^{1}$
}

Received: 16 March 2018 / Accepted: 8 October 2018 / Published online: 24 October 2018

(c) The Author(s) 2018

\begin{abstract}
Species distributions shift northwards due to climate change, but the ecological mechanisms allowing range expansions are not fully understood. Most studies have concentrated on breeding seasons, but winter warming may also be important. Wintering distributions are restricted by food availability and temperature, which may also interact. Foraging in cold conditions requires adaptations as individuals have to be efficient in foraging, while staying warm and vigilant for predators. When the ambient temperature declines, foraging rates should be reduced due to increased time spent on warming behaviours. In addition, predator vigilance should decline, because more time has to be invested in foraging. Cold weather should limit northward expanding southern species in particular, while northern species should perform better in cold conditions. We tested this by studying temperature responses (between 0 and $-35^{\circ} \mathrm{C}$ ) among wintering birds at feeders. We compared foraging behaviours of two northward expanding southern species, the great tit (Parus major) and the blue tit (Cyanistes caeruleus) to a northern species, the willow tit (Poecile montanus). Foraging rate and vigilance decreased, and warming behaviour increased when temperatures declined. Importantly, the performance in these traits was poorer in the southern species compared to the willow tit. Furthermore, the response to decreasing temperatures in foraging rates and warming behaviour was stronger in the great tits than willow tits. As the winters become warmer, these mechanisms should increase wintering success of southern species wintering at high latitudes, and lead to higher survival, increased population growth, and consequent range expansion.
\end{abstract}

Keywords Climate change $\cdot$ Non-breeding distribution $\cdot$ Survival $\cdot$ Warming behaviour $\cdot$ Wintering adaptation

\section{Introduction}

Climate change shifts species distributions polewards in most taxa (Thomas and Lennon 1999; Parmesan and Yohe 2003; Brommer et al. 2012; Lehikoinen and Virkkala 2016). To date, most studies have concentrated on breeding season phenological consequences of climate change (e.g., Visser et al. 1998; Vatka et al. 2011, 2014), while wintering ecology is less examined despite shortening winters

Communicated by Ola Olsson.

Electronic supplementary material The online version of this article (https://doi.org/10.1007/s00442-018-4271-7) contains supplementary material, which is available to authorized users.

Veli-Matti Pakanen

veli-matti.pakanen@oulu.fi

1 Ecology and Genetics Research Unit, University of Oulu, PO Box 3000, 90014 Oulu, Finland
(Sparks and Menzel 2002) that warm up the most (Jylhä et al. 2009). Warming of winters may be an important factor behind range expansion, because surviving the winter should become easier further north (Maclean et al. 2008; Zuckerberg et al. 2011; Lehikoinen et al. 2013; Fraixedas et al. 2015), but the ecological mechanisms allowing range expansions are not fully understood (Gaston 2009).

Winter is a demanding time in the northern latitudes. At the same time, when food availability is reduced, low temperatures require higher food consumption due to increased energy demands for heat production. For diurnal birds, shortened day lengths limit birds, because they have less time to acquire enough energy for their daily activities and for attaining sufficient fat deposits that ensure survival through the long and cold nights (e.g., Calder and King 1974; Biebach 1996; Koivula et al. 2002; Krams 2002; Krams et al. 2010). Successful wintering in cold conditions where temperatures can decline below $-30{ }^{\circ} \mathrm{C}$ requires morphological, physiological, and behavioural adaptations (e.g., Brooks 
1968; Biebach 1996), and alleviation in temperature should thus help southern species.

Wintering distributions are restricted to areas where the increased energy requirements of cold weather and metabolic rates do not grow too high (Root 1988, Meehan et al. 2004). Increasing winter temperatures reduce these requirements. Birds maintain their body temperatures partly by a high basal metabolic rate (BMR), which increases during the winter in many species (McKechnie 2008). When temperatures decline below the thermoneutral zone, basal metabolism, activity, and the heat increment of feeding do not produce enough heat (Calder and King 1974), and body temperatures are maintained by shivering thermogenesis (Hohtola et al. 1980; Hohtola 2004). Wintering birds use about $20-40 \%$ of their daily energy expenditure on heat production (Weathers et al. 1984; Weathers and Sullivan 1989). Consequently, wintering small birds are forced to forage large parts of the day (Austin 1974; Cooper 2000). Therefore, the ability to forage efficiently should be vital for acquiring energy reserves that ensure survival.

Winter distributions can be further limited by food availability in cases where physiological limitations do not restrict wintering (Repasky 1991; Canterbury 2002). A natural experiment occurs when winter feeding increases food availability and lures species into wintering in more northern locations than enabled by their adaptations. However, temperature seems to be more important than resources in determining wintering distributions (Zuckerberg et al. 2011), and these species of southern origin may still face problems in foraging in the cold environment.

Among birds, general adaptations to reduce energy and heat loss during the winter include finding less windy, warmer, and most profitable feeding and roosting sites (Sulkava 1968; Alatalo 1982; Wachob 1996; Vel'ký et al. 2010), reducing movements (e.g., Pakanen et al. 2018), using over-night hypothermia (Haftorn 1972; Reinertsen 1983; McKechnie and Lovegrove 2002), ptiloerection, and peripheral vasoconstriction, especially to keep their feet colder than their bodies (Johansen and Bech 1983). Unfeathered parts are an important avenue of heat loss in birds (Steen and Steen 1965, Hill et al. 1980, Yorzinski et al. 2018). Heat loss from legs can be reduced by vasoconstriction, but, at temperatures below freezing, birds have to use postural adjustments to cover the legs with insulating feathers for additional cold defense. This can curtail heat loss by 20-50\% (Dawson and Whittow 2000). Using ventral plumage for insulation by raising a foot or crouching may also be necessary to avoid cold bites at very low temperatures. However, such heat loss preventing behaviour may reduce foraging efficiency (Grubb 1978). This behaviour should increase with decreasing temperature, and be more common in the less adapted southern species.
During daily activities, individuals also need to scan the environment to escape depredation (Lendrem 1983; Treves 2000). However, there is a trade-off between time spent vigilant and foraging, which becomes a problem in cold conditions as birds need to increase foraging to meet their daily and over-night energy requirements (Caraco 1974; Hogstad 1988a, 2015 Pravosudov and Grubb 1995; Brodin et al. 2017). Reduced vigilance, in turn, may result in increased predation (Lind and Cresswell 2005). Therefore, wintering birds need to divide their daily activities between foraging, warming, and vigilance, and species that are best adapted to northern conditions should be better able to maintain foraging rates and vigilance in cold conditions, and allocate less time to warming behaviour.

Two temperate species, the great tit (Parus major) and the bue tit (Cyanistes caeruleus), have extended their breeding and wintering distributions to Northern Fennoscandia in the 20th century (Haartman et al. 1967; Väisänen et al. 1998; Valkama et al. 2011). Great tits reached northern parts of Fennoscandia in the late 1950s (Haftorn 1957; Veistola et al. 1995). Blue tits were very rare in the latter part of the 19th century being present only in the southernmost parts of Finland but extended their range across Finland during the 20th century (Valkama et al. 2011), reaching Oulu in greater numbers in the 1990s. While both species breed in northern Scandinavia, their densities are lower than in the south (Valkama et al. 2011). Winter feeding has influenced the winter distributions of these facultative migrants (Orell 1989; Nowakowski and Vähätalo 2003; Nilsson et al. 2006; Valkama et al. 2011). They commonly coexist with, and visit the same feeders as the willow tit (Poecile montanus) that are fully adapted to the northern conditions with territorial flocks that store food for the winter (Ekman 1989). While all species benefit from supplemental food (Lahti et al. 1998; Koivula et al. 1996; Jansson et al. 1981), the temperate species may be poorer in maintaining foraging rates due to lack of adaptations to the cold temperatures.

Here, we compared the performances of great tits and blue tits to the willow tit in the conditions of ample food (at feeders) in Northern Finland under temperatures ranging from 0 to $-35^{\circ} \mathrm{C}$. We used video recordings taken at feeders during winter to examine (1) how temperature affects the proportion of time which they can allocate to processing food (i.e. foraging rates), warming, and heat loss preventing behaviour and predator vigilance? We expected these behaviours to be dependent on temperature in all species, but we expected willow tits to have higher foraging rates and predator vigilance but show less warming behaviour. We further asked (2) whether the above species show different responses to temperature in these traits? As a boreal species, willow tits should be better adapted to cold conditions than the temperate species. Hence, they should be more efficient 
foragers, they should need to spend less time warming, and they should be able to be more vigilant in cold weather compared to the southern newcomers.

\section{Materials and methods}

\section{Study populations}

Foraging blue tits, great tits, and willow tits were video recorded in northern Finland sites along two temperature isotherms: (1) in Oulu, Hietasaari $\left(65^{\circ} 01^{\prime} \mathrm{N}, 25^{\circ} 28^{\prime} \mathrm{E}\right)$, Oulu, Sanginjoki $\left(64^{\circ} 95^{\prime} \mathrm{N}, 26^{\circ} 01^{\prime} \mathrm{E}\right)$, and Sonkajärvi $\left(63^{\circ} 40^{\prime} \mathrm{N}, 27^{\circ} 31^{\prime} \mathrm{E}\right)$, and (2) at Ranua $\left(65^{\circ} 92^{\prime} \mathrm{N}, 26^{\circ} 56^{\prime} \mathrm{E}\right)$ further in the north. Data from Oulu and Sonkajärvi were collected in 2010-2012 and data from Ranua in 2011-2012. Feeding sites were similar in terms of safe areas for reaching the feeders and for foraging. Thus, we consider the feeding sites to be equal in terms of predation risk effects on foraging and vigilance behaviour (Hogstad 1988b; Ekman 1987).

\section{Data collection and analysis}

We used Canon PowerShot A580 and Panasonic Lumix DMC-FZ18 digital cameras in recording videos of foraging tits, which were supplied with sunflower seeds and peanuts. We prevented disturbance to birds by filming from a car, through house windows or behind natural shelters from a distance of 5-10 m. We filmed foraging during daytime (9:00-15:00) when light conditions allowed filming. Length of the videos included in the study ranged from $10 \mathrm{~s}$ to a few minutes. Temperatures varied between $0{ }^{\circ} \mathrm{C}$ and $-35^{\circ} \mathrm{C}$. The data consisted of 241 video recordings (Oulu 115, Sonkajärvi 7, Ranua 119). There were videos from 34 blue tits, 152 great tits, and 55 willow tits that were similar in length and in ambient temperatures (Online resource 1). However, the coldest $-35{ }^{\circ} \mathrm{C}$ temperatures were recorded only for great tits. We, therefore, reran the statistical models (see below) with data spanning until $-30{ }^{\circ} \mathrm{C}$ to see if the coefficients stayed similar.

Videos were analysed using the program Anvil 5 (Kipp 2001), which can be used to determine time-budgets and quantify time-coded behavioural events. Starting from the time a bird fetched a seed/nut, we registered and marked the following parameters. (1) Foraging rate was measured as the proportion of time used in processing seeds from the overall time spent at the feeding site. We registered the starting and ending times of foraging, and the starting and ending times of pauses between foraging. Tits keep the seed in their toes when they process it with their bill (Yince 1964). (2) Warming behaviour was measured as the proportion of time that the seed was held in the beak. (3) Heat loss preventing behaviour was measured by whether the birds kept their feet most of the observed time under their feathers (coded 1) or not (coded 0$)$. We used a dichotomous $(0 / 1)$ variable, because the distribution was extremely discrete. In cold conditions, tits have to warm their toes inside their plumage (Dawson and Whittow 2000), and this was observed to affect foraging, either by totally disrupting it (indicated by holding the seed in the bill), or making it more difficult. (4) Vigilance was registered in timeline as events when the bird presumably scanned for possible predators by raising its head and stopped foraging activities.

We used linear mixed models (LMM) in program $\mathrm{R}(\mathrm{R}$ Development Core Team 2017) to analyse foraging rates, warming behaviour (the proportion of time seed was kept in the bill) and vigilance, and generalized linear mixed models (GLMM; binomial errors, logit link) to analyse heat loss preventing behaviour (legs hidden among feathers most of the time or not). We included species (willow tit as reference) and temperature during observation as fixed effects. The sites were divided into two temperature isotherms and site was included as a random effect with random annual slopes. We centred continuous variables to enable the proper interpretation of interaction models (Schielzeth 2010). We constructed several models starting with an intercept-model, and added temperature, species, and their interactions, consecutively, to find the best model explaining the variation in the studied behaviours. Model comparison was based on the Akaike Information Criterion (Burnham and Anderson 2002). In all cases, we were able to find the best model that was over two AIC-units better than the next best model. We did not individually mark birds, which meant that we could not include individual as a random factor. However, on the basis of a few colour ringed individuals, we could see that the within-individual variation was clearly larger than the between individual variation in the observed temperature scale. This means that the effect of temperature on behaviour should not be biased, even though some observations were made from the same individuals (Leger and Didrichsons 1994). Lack of data prevented us from including dominance rank, sex, or age of individuals in our models, even though they may be linked to vigilance behaviour (Krams 1998).

\section{Results}

\section{Foraging rates}

Overall foraging rates decreased with decreasing temperatures, and great tits and blue tits had lower foraging rates than willow tits (Fig. 1, Table 1). Foraging rate of great tits 


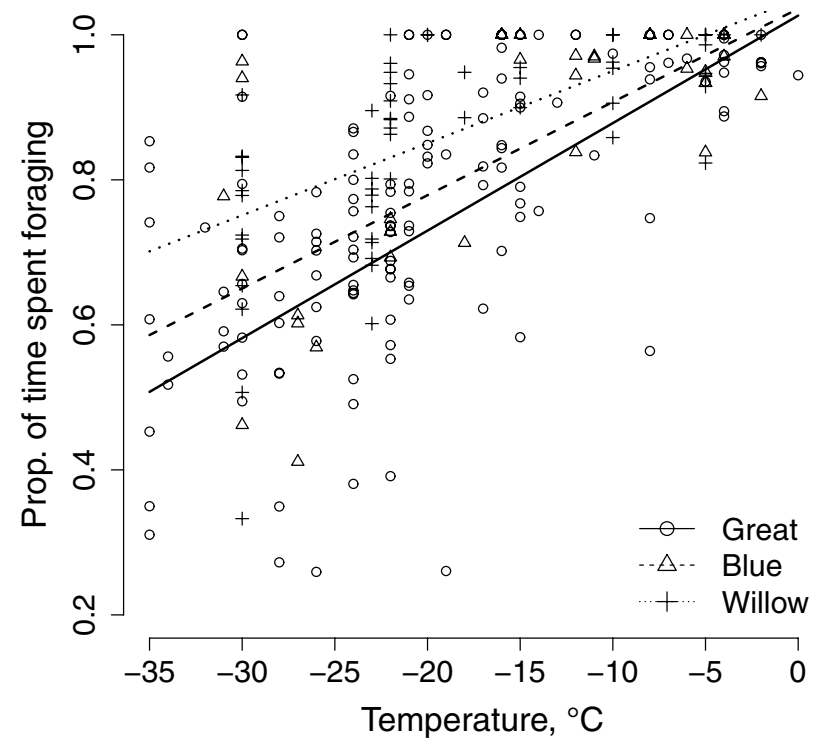

Fig. 1 Relationship between the foraging rate (proportion of time spent in foraging) and temperature for blue tits, great tits, and willow tits

reduced significantly faster in response to decreasing temperatures when compared to the willow tit (Fig. 1, Table 1). The coefficients remained similar in the data spanning until $-30{ }^{\circ} \mathrm{C}$ (Online Resource 2).

\section{Warming and heat loss preventing behaviour}

Warming behaviour increased in response to decreasing temperatures, and warming was more frequent in great tits and blue tits than in willow tits (Table 2; Fig. 2). Furthermore, the temperature response was stronger among great tits than in willow tits (Fig. 2; Table 2). This interaction was similar but did not remain significant in the data spanning until
$-30{ }^{\circ} \mathrm{C}$ (Online Resource 2). Heat loss preventing behaviour (covering legs with feathers) increased in response to decreasing temperatures, but there were no between-species differences (Fig. 3; Table 3). The coefficient remained similar in the data spanning until $-30{ }^{\circ} \mathrm{C}$ (Online Resource 2$)$.

\section{Vigilance}

Vigilance was reduced in response to decreasing temperature and consistently occurred less often in both blue tits and great tit compared to willow tits (Fig. 4; Table 4). The coefficient remained similar in the data spanning until $-30{ }^{\circ} \mathrm{C}$ (Online Resource 2).

\section{Discussion}

We found that foraging rates decreased, warming and heat loss preventing behaviour increased, and vigilance decreased in response to decreasing temperatures in all the species. As expected, the southern newcomers had lower foraging rates, more frequent warming behaviour, and were less vigilant compared to the better adapted boreal willow tits. It seems that even though wintering in the north is possible in terms of physiological aspects and available food, processing enough food to prevent death due starvation while escaping predation requires adaptations. These mechanisms acting in low temperatures may thus be important determinants of species winter ranges (Zuckerberg et al. 2011).

Willow tits had higher foraging rates than great tits and the decrease in the foraging rate in relation to lowering temperatures was stronger in the great tit than in the willow tit. In support of this, daily mass gain is the lowest during the coldest mid-winter months in great tits (Lehikoinen 1987), whereas willow tits do not show such variation (Broggi
Table 1 Best model estimates of parameters affecting foraging rates in blue tits, great tits, and willow tits in different temperatures $(\mathrm{zT}=$ centred temperature)

\begin{tabular}{lclrrr}
\hline Parameter & Coefficient & \multicolumn{1}{l}{ SE } & \multicolumn{1}{c}{$d f$} & \multicolumn{1}{l}{$Z$} & \multicolumn{1}{c}{$P$} \\
\hline Intercept & 0.862 & 0.032 & 6.095 & 27.197 & $<0.001$ \\
zTemperature (zT) & $\mathbf{0 . 1 8 0}$ & $\mathbf{0 . 0 3 7}$ & $\mathbf{2 2 9 . 6 5 7}$ & $\mathbf{4 . 8 9 8}$ & $<\mathbf{0 . 0 0 1}$ \\
Blue vs. willow & $\mathbf{- 0 . 0 6 9}$ & $\mathbf{0 . 0 3 3}$ & $\mathbf{4 7 . 7 7 7}$ & $\mathbf{- 2 . 1 0 4}$ & $\mathbf{0 . 0 4 1}$ \\
Great vs. willow & $\mathbf{- 0 . 1 1 5}$ & $\mathbf{0 . 0 2 7}$ & $\mathbf{9 . 8 9 4}$ & $\mathbf{- 4 . 2 8 4}$ & $\mathbf{0 . 0 0 2}$ \\
Blue $\times$ zT vs. Willow $\times$ zT & 0.053 & 0.056 & 215.426 & 0.933 & 0.352 \\
Great $\times$ zT vs. Willow $\times \mathbf{z T}$ & $\mathbf{0 . 0 8 8}$ & $\mathbf{0 . 0 4 4}$ & $\mathbf{2 3 0 . 7 2 8}$ & $\mathbf{2 . 0 2 5}$ & $\mathbf{0 . 0 4 4}$ \\
\hline Random effects: & Variance & SD & & & \\
\hline Site & 0.0006 & 0.0250 & & & \\
Year (2011) & 0.0027 & 0.0524 & & & \\
Year $(2012)$ & 0.0011 & 0.0328 & & & \\
Residual & 0.0174 & 0.1320 & & & \\
\hline
\end{tabular}

Statistically significant $(p \leq 0.05)$ parameters are in bold. The analysis included 240 observations from two sites (Mid-Finland and Lapland) 
Table 2 Best model estimates of parameters affecting warming behaviour (seed in the bill) in blue tits, great tits, and willow tits in different temperatures $(\mathrm{zT}=$ centred temperature $)$

\begin{tabular}{lclrrr}
\hline Parameter & Coefficient & \multicolumn{1}{l}{ SE } & \multicolumn{1}{c}{$d f$} & \multicolumn{1}{l}{$Z$} & \multicolumn{1}{c}{$P$} \\
\hline Intercept & 0.115 & 0.033 & 5.375 & 3.504 & 0.015 \\
zTemperature (zT) & $\mathbf{- 0 . 1 8 0}$ & $\mathbf{0 . 0 4 0}$ & $\mathbf{2 2 7 . 0 4 2}$ & $\mathbf{- 4 . 4 3 6}$ & $<\mathbf{0 . 0 0 1}$ \\
Blue vs. willow & $\mathbf{0 . 0 7 0}$ & $\mathbf{0 . 0 3 6}$ & $\mathbf{4 5 . 1 6 4}$ & $\mathbf{1 . 9 7 2}$ & $\mathbf{0 . 0 5 5}$ \\
Great vs. willow & $\mathbf{0 . 1 3 2}$ & $\mathbf{0 . 0 2 9}$ & $\mathbf{9 . 5 3 1}$ & $\mathbf{4 . 5 6 0}$ & $\mathbf{0 . 0 0 1}$ \\
Blue $\times$ zT vs. Willow $\times$ zT & -0.022 & 0.062 & 213.632 & -0.358 & 0.721 \\
Great $\times$ zT vs. Willow $\times \mathbf{z T}$ & $\mathbf{- 0 . 1 2 6}$ & $\mathbf{0 . 0 4 8}$ & $\mathbf{2 2 5 . 8 0 2}$ & $\mathbf{- 2 . 6 1 5}$ & $\mathbf{0 . 0 1 0}$ \\
\hline Random effects: & Variance & SD & & & \\
\hline Site & 0.0007 & 0.0259 & & & \\
Year $(2011)$ & 0.0034 & 0.0586 & & & \\
Year $(2012)$ & 0.0007 & 0.0268 & & & \\
Residual & 0.0215 & 0.1466 & & & \\
\hline
\end{tabular}

Statistically significant $(p \leq 0.05)$ parameters are in bold. The analysis included 237 observations from two sites (Mid-Finland and Lapland)

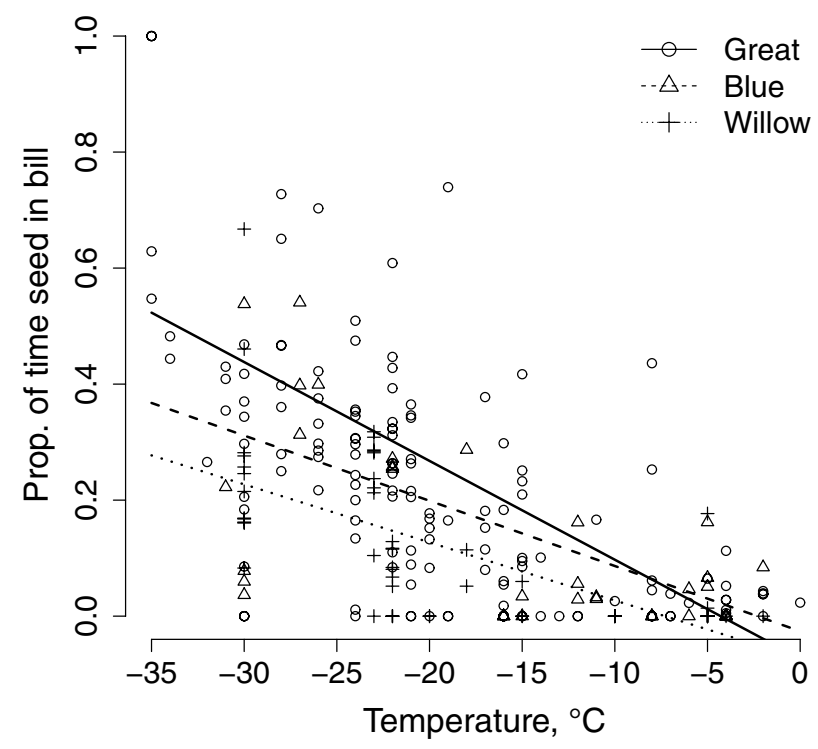

Fig. 2 Relationship between warming behaviour (as indicated by proportion of time the seed was held in the bill) and temperature for blue tits, great tits, and willow tits

et al. 2003). While great tits can somewhat benefit from the physiological and thermal benefits of their larger size (Lehikoinen 1986), reduced foraging rates can be a strain especially for the great tit which weighs nearly twice that of a willow tit, because energy consumption increases with size of the animal (McNab 1971; Calder and King 1974). Foraging was disturbed by warming behaviour when temperatures declined in all the species, but this change was stronger among great tits than willow tits. This result provides an explanation for the foraging rate difference in low temperatures, and suggests different seasonal adaptations to heat production in northern species (Carlson et al. 1993; Broggi et al. 2007; Petit et al. 2013) or species-specific

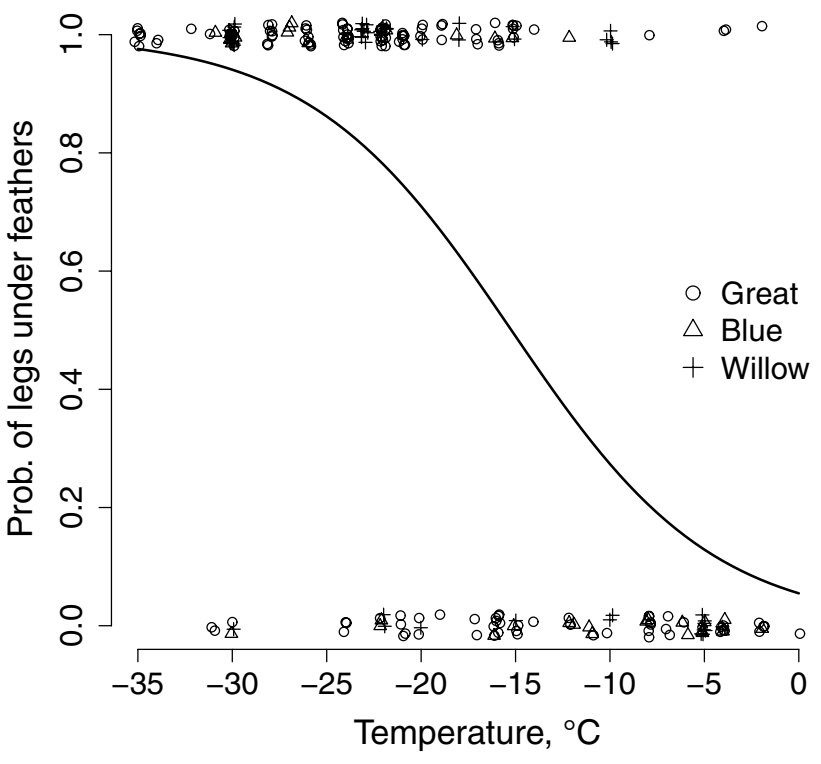

Fig. 3 Relationship between heat loss preventing behaviour (legs under feathers or not, see details in methods) and temperature for blue tits, great tits, and willow tits

cold tolerance and insulation properties of their plumage (Saarela et al. 1995). Indeed, great tits are unable to produce optimal feathers in northern conditions due to time and/or nutrient constraints, and this may lead to a plumage with poorer insulation properties (Broggi et al. 2011). Species differences in response to temperature may be evident only in the coldest temperatures as the interaction became less evident with the reduced data. This may also reflect the lack of data (and thus lower statistical power) for the complicated models that include the random effects of site with random slopes for years. 
Table 3 Best model estimates of parameters affecting heat loss preventing behaviour (covering legs with feathers) in blue tits, great tits, and willow tits in different temperatures $(\mathrm{T})$

\begin{tabular}{lllrl}
\hline Parameter & Coefficient & SE & $Z$ & $P$ \\
\hline Intercept & -2.8473 & 0.0002 & -12905.000 & $<0.001$ \\
Temperature $(\boldsymbol{T})$ & $\mathbf{- 0 . 1 8 7 1}$ & $\mathbf{0 . 0 0 0 2}$ & $\mathbf{- 8 5 6 . 0 0 0}$ & $<\mathbf{0 . 0 0 1}$ \\
\hline Random effects: & Variance & SD & & \\
\hline Site & 0.25446 & 0.5044 & & \\
Year (2011) & $6.22 \mathrm{E}+06$ & 2493.29 & & \\
Year (2012) & 0.05848 & 0.2418 & & \\
\hline
\end{tabular}

Statistically significant $(p \leq 0.05)$ parameters are in bold. The analysis included 228 observations from two sites (mid-Finland and Lapland)

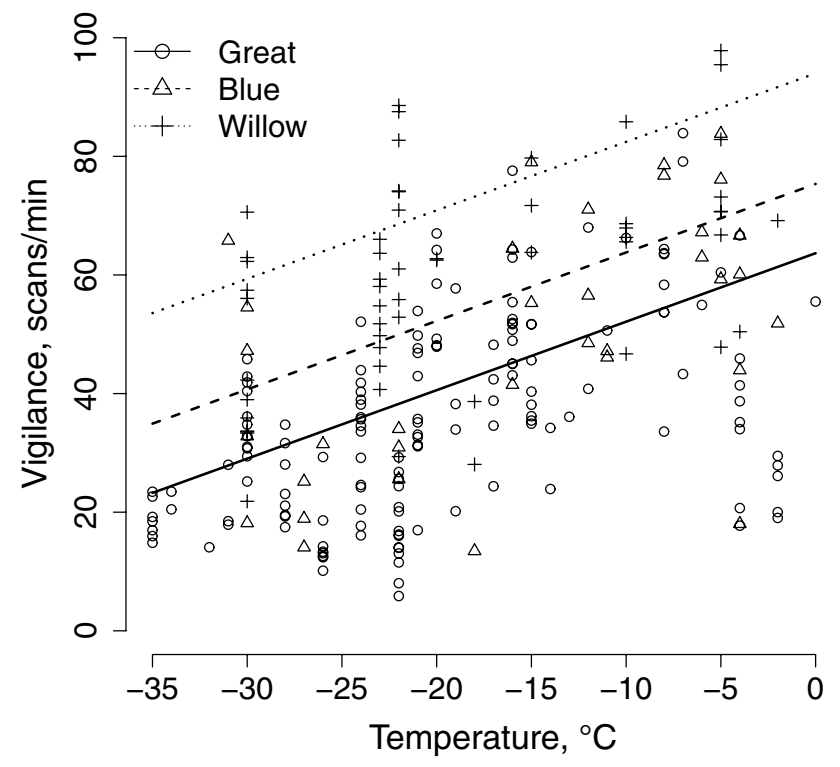

Fig. 4 Relationships between vigilance (scans/min) and temperature for blue tits, great tits, and willow tits

While blue tits had lower foraging rates and spent more time warming than willow tits, their responses to temperature were similar. It is possible that these behaviours are somewhat linked to morphology. Willow tits and blue tits have shorter feet and bills than great tits (Partridge 1976; Norberg 1979), which may reduce heat loss (Cardilini et al. 2016). Shorter legs also enable them to keep their centre of mass closer to the branch, which makes keeping the posture easier (Norberg 1979) and allows foraging even when their feet are almost covered by their plumage (own observations).

Heat loss preventing behaviour increased in response to cold temperatures similarly in all species. Birds may avoid heat loss preventing postures such as keeping legs within the plumage that can reduce reaction times to predation (Carr and Lima 2011), and use them mostly under extreme conditions when maintaining body or peripheral (leg) temperature becomes more important than escaping predation. In line with this, we found a threshold for feet warming (ca. $-20{ }^{\circ} \mathrm{C}$ ) below which this behaviour increased (Fig. 3). Birds have to cover their legs as heat loss becomes too high either for maintaining deep body temperature or for preventing freeze damage via the counter-current heat exchange between the arteries and veins. Energetically, it is cheaper to prevent cold damage by hiding the feet in feathers than by increasing the flow of arterial warm blood as this would further increase heat loss.

Vigilance reduced in all species when temperatures decreased. This result was similar to the previous studies
Table 4 Best model estimates of parameters affecting vigilance in blue tits, great tits, and willow tits in different temperatures $(T)$

\begin{tabular}{lrrrrr}
\hline Parameter & Coefficient & \multicolumn{1}{l}{ SE } & \multicolumn{1}{l}{$d f$} & \multicolumn{1}{l}{$Z$} & \multicolumn{1}{l}{$P$} \\
\hline Intercept & 93.997 & 3.909 & 4.590 & 24.049 & $<0.001$ \\
Temperature $(\boldsymbol{T})$ & $\mathbf{1 . 1 5 5}$ & $\mathbf{0 . 0 9 3}$ & $\mathbf{2 1 3 . 5 0 0}$ & $\mathbf{1 2 . 4 4 8}$ & $<\mathbf{0 . 0 0 1}$ \\
Blue vs. willow & $\mathbf{- 1 8 . 6 4 8}$ & $\mathbf{3 . 0 5 3}$ & $\mathbf{1 8 4 . 8 2 0}$ & $\mathbf{- 6 . 1 0 8}$ & $<\mathbf{0 . 0 0 1}$ \\
Great vs. willow & $\mathbf{- 3 0 . 3 2 5}$ & $\mathbf{2 . 4 6 5}$ & $\mathbf{6 7 . 5 9 0}$ & $\mathbf{- 1 2 . 3 0 4}$ & $<\mathbf{0 . 0 0 1}$ \\
\hline Random effects & Variance & SD & & & \\
\hline Site & 260.808 & 16.150 & & & \\
Year (2011) & 0.004 & 0.065 & & & \\
Year (2012) & 52.058 & 7.215 & & & \\
Residual & 155.160 & 12.456 & & & \\
\hline
\end{tabular}

Statistically significant $(p \leq 0.05)$ parameters are in bold. The analysis included 240 observations from two sites (mid-Finland and Lapland) 
(Caraco 1974; Hogstad 1988a, 2015; Pravosudov and Grubb 1995); nevertheless, great tits and blue tits scanned less than willow tits. This may be due to the better cold tolerance and higher foraging rate of willow tits. Information on food hoards may also reduce stress of accessing food, and thereby leave more time for vigilance.

Our results suggest that especially great tits have not fully adapted to the northern conditions, which is consistent with the previous studies on breeding great tits (Veistola et al. 1995; Rytkönen and Orell 2001; Krama et al. 2013). Birds respond to the cold by increasing metabolism, i.e., basal and summit metabolic rates (e.g., Petit et al. 2013). Resting great tits, for example, increase their metabolic rate to $3 \times \mathrm{BMR}$ at $-20{ }^{\circ} \mathrm{C}$ (Broggi et al. 2004, 2007), which requires the consumption of more food. However, during cold spells reaching $-35^{\circ} \mathrm{C}$, their foraging rate was reduced to nearly half. Low foraging rate may, therefore, be detrimental, especially when food is scarce and the day length is short. Great tits also move less during mid-winter in cold temperatures (Pakanen et al. 2018), which can make it even more difficult to find enough food. As a result, cold weather may result in starvation, stress, and eventually death (Krams et al. 2010, 2013). This is exacerbated by the poorer and reduced ability to keep vigilant in cold weather, making them vulnerable to predation (Morosinotto et al. 2017). It is, therefore, possible that cold temperatures limit success of great tits wintering in northern conditions by increasing mortality (Järvinen 1983). This conjecture is supported by an effect of winter temperature on annual survival (Perdeck et al. 2000) and the lower survival of breeding great tits in the north (0.38; Karvonen et al. 2012) compared to sympatric willow tits (0.59; Lampila et al. 2006) but also compared to great tits breeding in Central and Southern Europe (ca. 0.5; Payevsky 2006).

Here, we show that the southern newcomers wintering at high latitudes are not adapted to the cold temperatures in terms of foraging behaviour. Even when fed with supplemental food, their foraging rates and vigilance decreased in cold ambient temperatures and were lower than in a boreal species which is better adapted to the northern conditions. Climate change will undoubtedly help southern species winter at higher latitudes via processes such as earlier arrival of spring, increased proportion of bare ground, and less snow cover. Our results suggest that, if climate change increases winter temperatures and especially reduces the length and severity of cold spells in the northern latitudes, southern species will benefit from increased foraging rates and vigilance. These should result in higher survival, stronger population growth, and consequent range expansion towards the north.

Acknowledgements Open access funding provided by University of Oulu including Oulu University Hospital. VMP was supported by the Finnish Cultural Foundation. We are grateful to Juhani Karvonen, Kari Koivula, Jaana Mäkelä, Jukka Piispanen, and Sami Timonen who helped in organizing and maintaining feeding sites in Hietasaari, Oulu
2010-2012, and for the associate editor Ola Olsson, Indrikis Krams, and an anonymous referee for the valuable constructive comments on the manuscript. We thank Robert L. Thomson for language editing.

Author contribution statement SR and EA conceived the ideas and designed methodology; EA, EH, and SR collected the data. SR, EA, and VMP analysed the data. VMP and EA wrote the manuscript; other authors provided editorial advice.

\section{Compliance with ethical standards}

Conflict of interest The authors declare that they have no conflict of interest.

Ethical approval All applicable institutional and/or national guidelines for the care and use of animals were followed.

Data accessibility Data available from the Dryad Digital Repository: https://doi.org/10.5061/dryad.3f7hk01.

Open Access This article is distributed under the terms of the Creative Commons Attribution 4.0 International License (http://creativeco mmons.org/licenses/by/4.0/), which permits unrestricted use, distribution, and reproduction in any medium, provided you give appropriate credit to the original author(s) and the source, provide a link to the Creative Commons license, and indicate if changes were made.

\section{References}

Alatalo RV (1982) Effects of temperature on foraging behaviour of small forest birds wintering in northern Finland. Ornis Fenn 59:1-12

Austin GT (1974) Daily time budget of the postnesting Verdin. Auk $2: 247-251$

Biebach H (1996) Energetics of winter migratory fattening. In: Carey $\mathrm{C}$ (ed) Animal energetics and nutritional ecology. Chapman and Hall, New York, pp 280-323

Brodin A, Nilsson J-Å, Nord A (2017) Adaptive temperature regulation in the little bird in winter: predictions from a stochastic dynamic programming model. Oecologia 185:43-54

Broggi J, Koivula K, Lahti K, Orell M (2003) Seasonality in daily body mass variation in a hoarding boreal passerine. Oecologia 137:627-633. https://doi.org/10.1007/s00442-003-1355-8

Broggi J, Orell M, Hohtola E, Nilsson J-Å (2004) Metabolic response to temperature variation in the great tit: an interpopulation comparison. J Anim Ecol 73:967-972

Broggi J, Hohtola E, Koivula K, Orell M, Thomson RL, Nilsson J-Å (2007) Sources of variation in winter basal metabolic rate in the great tit. Func Ecol 21:528-533

Broggi J, Gamero A, Hohtola E, Orell M, Nilsson J-Å (2011) Interpopulation variation in contour feather structure is environmentally determined in Great tits. PLoS ONE 6:e24942

Brommer JE, Lehikoinen A, Valkama J (2012) The breeding ranges of Central European and Arctic bird species move poleward. PLoS ONE 7:e43648

Brooks WS (1968) Comparative adaptations of the Alaskan Redpolls to the Arctic environment. Wilson Bull 80:253-280

Burnham KP, Anderson DR (2002) Model selection and multimodel inference: a practical information-theoretic approach. Springer, New York 
Calder WA, King JR (1974) Thermal and caloric relations in birds. In: Farner DS, King JR, Parkes KC (eds) Avian biology, vol IV. Academic Press, New York, pp 259-413

Canterbury G (2002) Metabolic adaptation and climatic constraints on winter bird distribution. Ecology 83:946-957

Caraco T (1974) Time budgeting and group size: a test of theory. Ecology 60:618-627

Cardilini AP, Buchanan KL, Sherman CDL, Cassey P, Symonds MRE (2016) Tests of ecogeographical relationships in a non-native species: what rules avian morphology? Oecologia 181:783-793

Carlson A, Moreno J, Alatalo R (1993) Winter metabolism of coniferous forest tits (Paridae) under arctic conditions: a study with doubly labeled water. Ornis Scand 24:161-164

Carr JM, Lima SL (2011) Heat-conserving postures hinder escape: a thermoregulation-predation trade-off in wintering birds. Behav Ecol 23:434-441

Cooper SJ (2000) Seasonal energetic of Mountain chickadees and Juniper titmice. Condor 3:635-644

Dawson WR, Whittow GC (2000) Regulation of body temperature. In: Whittow GC (ed) Sturkie's avian physiology, 5th edn. Academic Press, New York, pp 343-390

Ekman J (1987) Exposure and time use in Willow tit flocks: the cost of subordination. Anim Behav 35:445-452

Ekman J (1989) Ecology of non-breeding social systems of Parus. Wilson Bull 101:263-288

Fraixedas S, Lehikoinen A, Lindén A (2015) Impacts of climate and land-use change on wintering bird populations in Finland. J Avian Biol 46:63-72

Gaston KJ (2009) Geographic range limits: achieving synthesis. Proc R Soc B Biol Sci 276:1395-1406

Grubb T (1978) Weather-dependent foraging rates of wintering woodland birds. Auk 95:370-376

Haartman L, Hildén O, Linkola P, Suomalainen P, Tenovuo R (1967) Pohjolan linnut värikuvin II. Otava, Helsinki, p 1092 (In Finnish)

Haftorn S (1957) Kjöttmeisas (Parus m. major L.) invandring og nåvarende utbredelse I Nord-Norge. Kongelige Norske Videnskaberns Selskabs Forhandlinger 30:14-21 (In Norwegian)

Haftorn S (1972) Hypothermia of tits in the Arctic winter. Ornis scandinavica 3:153-166

Hill RW, Beaver DL, Veghte JH (1980) Body-surface temperatures and thermoregulation in the black-capped chickadee (Parus atricapillus). Physiol Zool 53:305-321

Hogstad O (1988a) Advantages of social foraging of Willow tits Parus montanus. Ibis 130:275-283

Hogstad O (1988b) Social rank and antipreator behavior of Willow tits Parus montanus in winter flocks. Ibis 130:45-56

Hogstad O (2015) Rank-related response in foraging site selection and vigilance behaviour of a small passerine to different winter weather conditions. Ornis Fenn 92:53-62

Hohtola E (2004) Shivering thermogenesis in birds and mammals. In: Barnes BM, Carey HV (eds) Life in the cold: evolution, mechanisms, adaptation, and application. Twelfth international hibernation symposium. Biological papers of the university of Alaska, 27. Fairbanks, Alaska, pp 241-252

Hohtola E, Rintamäki H, Hissa R (1980) Shivering and ptiloerection as complementary cold defence responses in the pigeon during sleep and wakefulness. J Comp Physiol 136:77-81

Jansson C, Ekman J, Brömssen A (1981) Winter mortality and food supply in tits Parus spp. Oikos 37:313-322

Järvinen A (1983) Breeding strategies of hole-nesting passerines in northern Lapland. Ann Zool Fenn 20:129-149

Johansen K, Bech C (1983) Heat conservation during cold exposure in birds (vasomotor and respiratory implications). Polar Res $1: 259-268$

Jylhä K, Ruosteenoja K, Räisänen J, Venäläinen A, Tuomenvirta H, Ruokolainen L, Saku S, Seitola T (2009) Arvioita Suomen muuttuvasta ilmastosta sopeutumistutkimuksia varten. ACCLIMhankkeen raportti 2009 (The changing climate in Finland: estimates for adaptation studies. ACCLIM project report 2009). Reports 2009. Finnish Meteorological Institute, Helsinki (in Finnish)

Karvonen J, Orell M, Rytkönen S, Broggi J, Belda E (2012) Population dynamics of an expanding passerine at the distribution margin. $\mathrm{J}$ Avian Biol 43:102-108

Kipp M (2001) Anvil - a generic annotation tool for multimodal dialogue. In: Proceedings of the 7th European Conference on Speech Communication and Technology (Eurospeech), pp 1367-1370

Koivula K, Orell M, Rytkönen S (1996) Winter survival and breeding success of dominant and subordinate Willow tits Parus montanus. Ibis 138:624-629

Koivula K, Orell M, Lahti K (2002) Plastic daily fattening routines in willow tits. J Anim Ecol 71:816-823

Krama T, Suraka V, Hukkanen M, Rytkönen S, Orell M, Cīrule D, Rantala MJ, Krams I (2013) Physiological condition and blood parasites of breeding Great Tits: a comparison of core and northernmost population. J Ornithol 154:1019-1028

Krams I (1998) Dominance-specific vigilance in the Great tit. J Avian Biol 29:55-60

Krams I (2002) Length of feeding day and body weight of Great tits in a single- and a two-predator environment. Behav Ecol Sociobiol 48:147-153

Krams I, Cīrule D, Suraka V, Krama T, Rantala MJ, Ramey G (2010) Fattening strategies of wintering great tits support the optimal body mass hypothesis under conditions of extremely low ambient temperature. Funct Ecol 24:172-177

Krams I, Cīrule D, Vrublevska J, Nord A, Rantala MJ, Krama T (2013) Nocturnal loss of body reserves reveals high survival risk for subordinate great tits wintering at extremely low ambient temperatures. Oecologia 172:339-346

Lahti K, Orell M, Rytkönen S, Koivula K (1998) Time and food dependence in Willow tit winter survival. Ecology 79:2904-2916

Lampila S, Orell M, Belda E, Koivula K (2006) Importance of adult survival, local recruitment and immigration in a declining boreal forest passerine, the willow tit Parus montanus. Oecologia 148:405-413

Leger DW, Didrichsons IA (1994) An assessment of data pooling and some alternatives. Anim Behav 48:823-832

Lehikoinen E (1986) Dependence of winter survival on size in the Great tit Parus major. Ornis Fenn 63:10-16

Lehikoinen E (1987) Seasonality of the daily weight cycle in wintering passerines and its consequences. Ornis Scand 18:216-226

Lehikoinen A, Virkkala R (2016) North by north-west: climate change and directions of density shifts in birds. Glob Change Biol 22:1121-1129

Lehikoinen A, Jaatinen K, Vähätalo AV, Clausen P, Crowe O, Deceuninck B, Hearn R, Holt CA, Hornman M, Keller V, Nilsson L, Langendoen T, Tománková I, Wahl J, Fox AD (2013) Rapid climate driven shifts in wintering distributions of three common waterbird species. Glob Change Biol 19:2071-2081

Lendrem DW (1983) Predation risk and vigilance in the blue tit (Parus caeruleus). Behav Ecol Sociobiol 14:9-13

Lind J, Cresswell W (2005) Determining the fitness consequences of antipredation behavior. Behav Ecol 16:945-956

Maclean IMD, Austin GE, Rehfisch MM, Blew J, Crowe O, Delany S, Devos K, Deceuninck B, Günther K, Laursen K, Van Roomen M, Wahl J (2008) Climate change causes rapid changes in the distribution and site abundance of birds in winter. Glob Change Biol 14:2489-2500

McKechnie AE (2008) Phenotypic flexibility in basal metabolic rate and the changing view of avian physiological diversity: a review. J Comp Physiol B 178:235-247 
McKechnie AE, Lovegrove BG (2002) Avian facultative hypothermic responses: a review. Condor 104:705-724

McNab BK (1971) On the ecological significance of Bergmann's Rule. Ecology 52:845-854

Meehan TD, Jetz W, Brown JH (2004) Energetic determinants of abundance in winter landbird communities. Ecol Lett 7:532-537

Morosinotto C, Villers A, Varjonen R, Korpimäki E (2017) Food supplementation and predation risk in harsh climate: interactive effects on abundance and body condition of tit species. Oikos 126:863-873

Nilsson ALK, Lindström ̊̊, Jonzén N, Nilsson SG, Karlsson L (2006) The effect of climate change on partial migration-the blue tit paradox. Glob Change Biol 12:2014-2022

Norberg UM (1979) Morphology of the wings, legs and tail of three coniferous forest tits, the goldcrest, and the treecreeper in relation to locomotor pattern and feeding station selection. Philos Trans R Soc Lond 287:131-165

Nowakowski JK, Vähätalo AV (2003) Is the great tit Parus major an irruptive migrant in North-east Europe? Ardea 91:231-244

Orell M (1989) Population fluctuations and survival of great tits Parus major dependent on food supplied by man in winter. Ibis 131:112-127

Pakanen VM, Karvonen J, Mäkelä J, Hietaniemi J-P, Jaakkonen T, Kaisanlahti E, Kauppinen M, Koivula K, Luukkonen A, Rytkönen S, Timonen S, Tolvanen J, Vatka E, Orell M (2018) Cold weather increases winter site fidelity in a group living passerine. J Ornithol 159:211-219

Parmesan C, Yohe G (2003) A globally coherent fingerprint of climate change impacts across natural systems. Nature 421:37-42

Partridge L (1976) Some aspects of the morphology of the blue tits (Parus caeruleus) and Coal tits (Parus ater) in relation to their behavior. J Zool 179:121-133

Payevsky VA (2006) Mortality rate and population density regulation in the Great tit, Parus major L.: a review. Russ J Ecol 37:180-187

Perdeck AC, Visser ME, Van Balen JH (2000) Great tit Parus major survival and the beech-crop cycle. Ardea 88:99-106

Petit M, Lewden A, Vézina F (2013) Intra-seasonal flexibility in avian metabolic performance highlights the uncoupling of basal metabolic rate and thermogenic capacity. PLoS ONE 8(6):e68292

Pravosudov VV, Grubb TC (1995) Vigilance in the tufted titmouse varies independently with air temperature and conspecific group size. Condor 97:1067-1070

R Development Core Team (2017) R: a language and environment for statistical computing. R Foundation for Statistical Computing. http://www.r-project.org/. Accessed 30 Oct 2017

Reinertsen RE (1983) Nocturnal hypothermia and its energetic significance for small birds living in the arctic and subarctic regions. A review. Polar Research 1:269-284

Repasky RR (1991) Temperature and the northern distributions of wintering birds. Ecology 72:2274-2285

Root T (1988) Energy constraints on avian distributions and abundances. Ecology 69:330-339

Rytkönen S, Orell M (2001) Great tits, Parus major, lay too many eggs: experimental evidence in mid-boreal habitats. Oikos 93:439-450
Saarela S, Klapper B, Heldmaier G (1995) Daily rhythm of oxygen consumption and thermoregulatory responses in some European winter or summer-acclimatized finches at different ambient temperatures. J Comp Physiol B 165:366-376

Schielzeth H (2010) Simple means to improve the interpretability of regression coefficients. Methods Ecol Evol 1:103-113

Sparks TH, Menzel A (2002) Observed changes in seasons: an overview. Int J Climatol 22:1715-1725

Steen I, Steen JB (1965) The importance of the legs in the thermoregulation of birds. Acta Physiol Scand 63:285-291

Sulkava S (1968) On small birds spending the night in the snow. Aquilo Ser Zool 7:33-37

Thomas CD, Lennon JJ (1999) Birds extend their ranges northwards. Nature 399:213

Treves A (2000) Theory and method in studies of vigilance and aggregation. Anim Behav 60:711-722

Väisänen RA, Lammi E, Koskimies P (1998) Muuttuva pesimälinnusto. Otava, Helsinki, p 567 (in Finnish)

Valkama J, Vepsäläinen V, Lehikoinen A (2011) The third Finnish breeding bird atlas. Finnish Museum of Natural History and Ministry of Environment. http://atlas3.lintuatlas.fi/english. Accessed 2 Feb 2018 (ISBN: 978-952-10-7145-4)

Vatka E, Orell M, Rytkönen S (2011) Warming climate advances breeding and improves synchrony of food demand and food availability in a boreal passerine. Glob Change Biol 17:3002-3009

Vatka E, Rytkönen S, Orell M (2014) Does the temporal mismatch hypothesis match in boreal populations? Oecologia 176:595-605

Veistola S, Lehikoinen E, Iso-Iivari L (1995) Breeding biology of the great tit Parus major in a marginal population in northernmost Finland. Ardea 83:419-420

Vel'ký M, Kaňuch P, Krištín A (2010) Selection of winter roosts in the Great tit Parus major: influence of microclimate. J Ornithol 151:147-153

Visser ME, van Noordwijk AJ, Tinbergen JM, Lessells CM (1998) Warmer springs lead to mistimed reproduction in great tits (Parus major). Proc R Soc B 265:1867-1870

Wachob DG (1996) The effect of thermal microclimate on foraging site selection by wintering Mountain Chickadees. Condor 98:114-122

Weathers WW, Sullivan KA (1989) Juvenile foraging proficiency, parental effort and avian reproductive success. Ecol Monogr 59:223-246

Weathers WW, Buttermer WA, Hayworth AM, Nagy KA (1984) An evaluation of time-budget estimates of daily energy expenditure in birds. Auk 101:459-472

Yince MA (1964) Use of the feet in feeding by the Great tit Parus major. Ibis 106:508-529

Yorzinski JL, Lam J, Schultz R, Davis M (2018) Thermoregulatory postures limit antipredator responses in peafowl. Biology Open 7:bio031005. https://doi.org/10.1242/bio.031005

Zuckerberg B, Bonter DN, Hochachka WM, Koenig WD, DeGaetano AT, Dickinson JL (2011) Climatic constraints on wintering bird distributions are modified by urbanization and weather. J Anim Ecol 80:403-413 